\title{
PHYSICAL ACTIVITY, EATING HABITS AND SLEEP DURING SOCIAL ISOLATION: FROM YOUNG ADULT TO ELDERLY
} AOIDOSO

\author{
ACTIVIDAD FISICA, HÁBITOS ALIMENTARIOS Y SUEÑO DURANTE EL AISLAMIENTO SOCIAL:DESDE \\ EL JOVEN A LA TERCERA EDAD
}

\begin{abstract}
Lilian Messias Sampaio Brito' (ID (Physical Education Professional) Valderi Abreu de Lima' (DD) (Physical Education Professional) Luis Paulo Mascarenhas² (1D (Physical Education Professional) Jorge $\operatorname{Mota}^{3}$ (iD)

(Physical Education Professional) Neiva Leite ${ }^{1,3}$ (ID

(Physical Education Professional, Medical Doctor)
\end{abstract}

1. University Federal of Parana, Physical Education Department, Curitiba, PR, Brazil.

2. Midwestern Parana State University, Physical Education Department, Guarapuava,

PR, Brazil.

3. University of Porto, Faculty of Sport, Porto, Portugal.

\section{Correspondence:}

Lilian Messias Sampaio Brito. Physical Education Department. Rua Coração de Maria, 92, Jardim Botânico, Curitiba, PR, Brazil. 80050-540.

lilianmessias@yahoo.com.br

\begin{abstract}
Introduction: Social isolation is one of the strategies used to prevent the contagion and transmission of the coronavirus (COVID-19), but it impacts on the daily routines and lifestyle of the population. Objective: Therefore, the aim of this study was to analyze the physical activity, sleep and eating habits of adults and the elderly during the COVID-19 pandemic. Method: A cross-sectional study with a sample comprising 135 participants, divided by age group. First, the whole group was divided into age groups with a 10-year cut-off. They were then characterized by sex, type of home, eating habits, sleep, and physical activity. For the second analysis, the participants were organized into three groups: young adults (18-40 years), middle-aged adults (41-60 years) and elderly ( $>60$ years). An online questionnaire was sent to all the participants, with 26 questions focusing on eating habits, sleep, protective behaviors against COVID-19, and physical activity. Results: The participants were mainly women (85.9\%), external community (71.1\%), students' families (17.1\%), teachers and staff (11.8\%). Of the total participants, $40 \%$ were dedicated to home care activities and $21.1 \%$ had started working from home. The remainder (38.9\%) were engaged in activities such as studying or caring for dependents. The younger age group (18-40 years old) reported spending more time in sedentary activities during the day, and $34.2 \%$ did not perform physical activity and ate lower quality food during social isolation $(p<0.01)$. All groups, with the exception of the $30-40$ age group ( $p<0.01$ ) highlighted the importance of having the presence of a teacher responsible for guiding physical activities during isolation. Conclusion: We conclude that, social isolation has more negative impact on the habits of the younger group. Cross-sectional study.
\end{abstract}

Keywords: Pandemic; Aging; Adults; Exercise; Brazil.

\section{RESUMO}

Introdução: O isolamento social é uma das estratégias de prevenção do contágio e transmissão do coronavírus (COVID-19), porém tem impacto na rotina diária e no estilo de vida da população. Objetivo: Assim sendo, o objetivo deste estudo foi analisar atividade física, sono e hábitos alimentares de adultos e idosos durante a pandemia de COVID-19. Métodos: Estudo transversal com amostra de 135 participantes divididos por faixa etária. No início, todo o grupo foi dividido em grupos etários com corte de 10 anos. A seguir, foram caracterizados por sexo, tipo de residência, hábitos alimentares, sonoe atividade física. Para a segunda análise, os participantes foram organizados em três grupos: adultos jovens (18 a 40 anos), adultos de meia-idade (41 a 60 anos) e idosos (> 60 anos). Um questionário online foi enviado a todos os participantes, com 26 questões concentradas em hábitos alimentares, sono, comportamentos de proteção contra a COVID-19 e atividade física foienviado a todos os participantes. Resultados: Os participantes eram principalmente mulheres (85,9\%), estudantes universitários $(71,1 \%)$, familiares dos alunos $(17,1 \%)$, professores e funcionários (11,8\%). Do total dos participantes, $40 \%$ eram dedicados às atividades domésticas e $21,1 \%$ começaram a trabalhar em casa. Orestante (38,9\%) exercia atividades como estudar ou cuidar de dependentes. A faixa etária mais jovem (18 a 40 anos) relatou passar mais tempo em atividades sedentárias durante o dia, e 34,2\% não praticavam atividade física e consumiam alimentos com menor teor nutritivo durante o isolamento social ( $p<0,01)$. Todos os grupos, com exceção da faixa etária de 30 a 40 anos $(p<0,01)$, destacaram a importância da presença de um professor responsável por orientar as atividades físicas durante o isolamento. Conclusão: Concluímos que o isolamento social tem impacto mais negativo nos hábitos do grupo mais jovem. Estudo transversal.

Descritores: Pandemias; Envelhecimento; Adulto; Exercício físico; Brasil.

\section{RESUMEN}

Introducción: El aislamiento social es una de las estrategias de prevención del contagio y transmisión del coronavirus (COVID-19), aunque tiene un impacto en la rutina diaria y el estilo de vida de la población. Objetivo: Siendo así, el objetivo de este estudio fue analizar la actividad física, el sueño y los hábitos alimentarios de adultos y personas de la tercera edad durante la pandemia de COVID-19. Métodos: Estudio transversal con muestra de 135 participantes divididos por grupo de edad. Al inicio, todo el grupo fue dividido en grupos de edad con corte de 10 años. A continuación, fueron 
caracterizados por sexo, tipo de residencia, hábitos alimentarios, sueño y actividad física. Para el segundo análisis, los participantes fueron organizados en tres grupos: adultos jóvenes (18 a 40 años), adultos de mediana edad (41 a 60 años) y personas de la tercera edad (> 60 años). Fue enviado un cuestionario en línea a todos los participantes con 26 cuestiones concentradas en hábitos alimentarios, sueño, comportamientos de protección contra la COVID-19y actividad fisica. Resultados: Los participantes eran principalmente mujeres (85,9\%), estudiantes universitarios $(71,1 \%)$, familiares de los alumnos (17,1\%), profesores y funcionarios (11,8\%). Del total de los participantes, $40 \%$ se dedicaba a actividades domésticas y 21,1\% comenzó a trabajar en casa. El resto (38,9\%) ejercía actividades como estudiar o cuidar a dependientes. El grupo de edad más joven (18 a 40 años) relató pasar más tiempo en actividades sedentarias durante el día, y 34,2\% no practicaba actividad fisica y consumía alimentos con menor tenor nutritivo durante el aislamiento social $(p<0,01)$. Todos los grupos, con excepción del grupo de edad de 30 a 40 años $(p<0,01)$ destacaron la importancia de la presencia de un profesor responsable por orientar las actividades físicas durante el aislamiento. Conclusión: Concluimos que el aislamiento social tiene impacto más negativo en los hábitos del grupo más joven. Estudio transversal.

Descriptores: Pandemias; Envejecimiento; Adulto; Ejercicio Físico; Brasil.

\section{INTRODUCTION}

The daily routine consists of many activities, such as sleeping, eating and physical activity, which are components of people's lifestyle. The options and availability of activities, in general, depend on the age group, as well as the organization of life related to school, work and family members' commitments. ${ }^{1}$ However, this routine was altered drastically due to the possibility of contamination by corona virus disease (COVID-19) in Brazil, especially after the World Health Organization labeled COVID-19 declaring it a pandemic in March2020. 'As a result, social isolation was the strategy adopted to control the infection leading towards changes in life habits. Indeed, as it is an unknown virus and given the lack of treatments and vaccines based on the evidence available for COVID-19, public health actions are extremely important, and social distance is recommended for infection control. ${ }^{2,3}$

Home office practices were adopted as non-essential services, remote studies, in addition to families with school-age children. ${ }^{1}$ In addition to the concern with contamination by COVID-19, there were restrictions or changes in different situations in the daily lives of families, namely some restriction of physical activity and changes in sleep and eating habits. ${ }^{4}$ Thus, the reduction in physical activity levels, is of concern in adult and older individuals, who are typically more inactive than younger people and prone to frailty, sarcopenia and chronic illnesses. ${ }^{5}$

Therefore, the lack of activities in the daily routine of adults and the elderly is a concern once sedentary habits and excess weight are factors that predispose the subclinical inflammatory process, ${ }^{5}$ a risk factor that has been reported as associated a further complication of COVID-19.1

However, the reality within each family can be different, with adjustments in activities of daily living, even with reduced opportunities to practice their physical activities and conduct a routine of training in outdoor activities, with parks and gyms closed. Thus, the aim of this study is to analyze the behavior of adults and the elderly regarding sleep habits, food and physical activities in times of pandemic, during the isolation recommended to prevent COVID-19.

\section{MATERIALS AND METHODS}

This observational, cross-sectional study was conducted with a sample of 135 adults (85.9\% female and $14.1 \%$ male). The sample was taken from a group of 250 adult volunteers who regularly participate in physical activities in a school community program. The male distribution young adults were $(n=7,5.2 \%)$, middle-age $(n=8,6.0 \%)$ and old $(n=3,2.2 \%)$. Distribution among women were middle-age adults $(n=69$, $51.1 \%)$, young adults $(n=31,23 \%)$ and old $(n=17,12.6 \%)$.
The participants were analyzed in two different ways, the first the whole group, subdivided every ten years, and the second grouped into three categories, according to the stage in life: young adults (18-40 years), middle-age adults (41-60 years) and old (>60 years). It is understood that each of these phases has specific milestones of experiences: young adults are characterized by the phase of the beginning of professional life, of the constitution of a family, whereas the middle young phase is yet another phase in which there is professional and personal stability. And finally, we understand that the phase above 60 years is the phase of serenity, of enjoying everything that was built in a lifetime. ${ }^{6}$

Participants are older than 18-year-old (fathers, mothers, teachers, staff and community) from both genders and attending one state public school in the municipality of Curitiba, Parana, south region of Brazil. The participants were selected by convenience, using the non-probabilistic sampling process, and the $\mathrm{G}$ * Power software was used to determine the sample size. From the population of 250 adults, a power of 0.80 , with 95\% confidence level and 5\% sampling error, totalizing 121 participants. with a sample of 135 adults.

All adults enrolled in regular sport activities were invited to participate in this study. Inclusion criterion was all adults enrolled in any physical activity in 2020 at the school, and the exclusion criterion was those who did not answer the open question in a consistent manner with what was being asked.

The online form (Google docs) comprising 26 closed and one open question was applied. The questionnaire was sent via a web link by their coach during the second half of May 2020. The participants had one week to answer the questions. The questionnaire included questions regarding age, sex, number of residents at home, type of residence, risk groups in the family, who was working outside the home, eating habits, sleep, and physical activity. In addition, it was asked whether the adult received some assistance from the government or the community and if he needed any emergency help in this moment.

The questions were based on scientific evidence (recommendations about physical activity, ${ }^{7}$ eating ${ }^{8}$ and sleeping $)^{9}$ according to the age group and were mandatory. The questions were organized into sections: the first question was the identification in the school community, if he was a father/mother, teacher, then the characteristics of the environment, housing type, how many people live in the same house, working from home and risk factors for COVID-19. The second section included three questions related to physical activity, time when the adult remained active during the week (meet or not the WHO guidelines), if he answered yes, what type and intensity of physical activity and with whom he practiced, and the place in his home he used to exercise (rooms in 
the house, corridor, covered outdoor area, outdoor uncovered area or garden, common area of the condominium), two questions related to eating (recommended number of meals and eating habits, irregular feeding and quality), and sleeping (adequate and inadequate) behaviors and quality of the sleep.

The forms included the Invitation Letter, the Informed Consent Form and the Term of Assent for participation in the study in the beginning. The researchers checked the questionnaire before being applied with adults in order to identify errors.

\section{Statistical Methods}

The variables were expressed as mean and standard deviation, as well as absolute and relative frequencies. The categorical variables were assessed via Pearson / Yates chi-squared test. The chi-square test was used to analyze the correlations between age groups with physical activity variables, sleep, eating habits. To verify the differences between the habits of the age groups, they were organized into three groups: young adults, middle-age adults and old years. ${ }^{6}$ To evaluate the responses regarding doing physical activity with the physical education professional or otherwise by age group we use the chi-square test. Statistical significance was set at an alpha level of $p<0.05$. All analyses were performed in the Statistic software, version10.0 Enterprise (Cary, NC, USA).

\section{Ethics Committee}

A consent form explaining the research objectives and questions to be applied was read and signed by the parents or legal guardians. The study conducted in public schools was approved by the Ethics Committee on Human Research of the Federal University of Paraná under protocol CEP 4.018.525/2020 and CAAE:08389212.6.0000.0096, in accordance with Resolution number 466 of December 12th 2012, of the National Health Council. Ethics Committee approval was updated in April 2020.

\section{RESULTS}

In this study participated 135 adults (85.9\% women). Table 1 shows the characteristics of the entire group, regardless of age group division. And, also, the distribution of the questionnaire responses in relation to socioeconomic and socio-demographic data.

Research has shown that most of the participants live at home (53.3\%). In 94.1\% of cases, they reported taking care and $95 \%$ received guidance on COVID-19. About one third (33\%) received guidance on care through television programs, while $6.6 \%$ of participants received financial assistance from the government. The analysis performed in table 1 by age showed the importance of having a physical education professional teaching classes to maintain physical activity, only the group from 31-40 age group looked for different ways to maintain their physical activities, seeking classes on social networks or cell phone applications, performing exercises that I already did before the pandemic $(p<0.01)$. The characteristics are shown in Table 1.

The table 2 shows results for the three categories (young adults, middle-age adults and old) regarding physical activity, eating and sleeping habits. We can observe statistical significant differences among age-groups for type of housing, the use of time in moderate-vigorous activities, the quality of food, regular physical activity as well as the teacher physical activities guidance $(p<0.01)$.

\section{DISCUSSION}

The present study showed that most of the participants remained active during the first months of social isolation with the exception of young adults. (Table 2) Maintaining an active routine is important since, according to the World Health Organization, approximately 3.2 million deaths per year are attributed to physical inactivity and a sedentary lifestyle. ${ }^{10}$
Table 1. Absolute and relative frequency of sociodemographic, socioeconomic and health-related behaviors variables of school community.

\begin{tabular}{c|c}
\hline Answers & $\mathbf{n}(\%)$ \\
\hline \multicolumn{2}{c}{ Sociodemographic and socioeconomic } \\
\hline \multicolumn{2}{c}{ Age } \\
\hline 18-30 years & $15(11.1)$ \\
\hline 31-40 years & $24(17.7)$ \\
\hline 41-50 years & $35(25.9)$ \\
\hline 51-60 years & $41(30.4)$ \\
\hline 61-70 years & $17(12.6)$ \\
\hline Above 71 years & $3(2.2)$ \\
\hline Member you represent in the school community \\
\hline External community & $96(71.1)$ \\
\hline Teacher or school employee & $16(11.8)$ \\
\hline \multicolumn{2}{c}{ Student family } \\
\hline
\end{tabular}

How do you spend your day during social isolation

\begin{tabular}{c|c}
\multicolumn{2}{c}{ How do you spend your day during social isolation } \\
\hline Taking care of the home & $54(40)$ \\
\hline Studying & $15(11.1)$ \\
\hline Home office & $38(21.1)$ \\
\hline Social network, tablet, cell phone & $14(10.4)$ \\
\hline Taking care of child, parents, grandparents & $1(0.7)$ \\
\hline Watching television & $8(6)$ \\
\hline Doing physical activity & $5(3.7)$ \\
\hline
\end{tabular}

Number of people live in your home besides you

\begin{tabular}{c|c}
\hline 1 person & $34(25.2)$ \\
\hline 2 people & $46(34.1)$ \\
\hline 3 people & $23(17)$ \\
\hline 4 people & $9(6.6)$ \\
\hline Above 4 people & $6(4.5)$ \\
\hline Alone & $17(12.6)$ \\
\hline
\end{tabular}

Number of people that are working outside

\begin{tabular}{c|c}
\hline \multicolumn{2}{c}{ Number of people that are working outside } \\
\hline 1 person & $46(34.1)$ \\
\hline 2 people & $28(20.7)$ \\
\hline Above 2 people & $5(3.7)$ \\
\hline Home office & $27(20)$ \\
\hline None of the answers & $29(21.5)$
\end{tabular}

In your home there are people at risk for COVID-19

\begin{tabular}{c|c}
\hline No & $4(2.9)$ \\
\hline Yes & $85(97.1)$ \\
\hline Who or where received guidance on COVID-19 \\
\hline Friends, family, work & $35(26.3)$ \\
\hline Television & $35(26.3)$ \\
\hline Social networks & $45(33.9)$ \\
\hline Font: The authors (2020); & $18(13.5)$ \\
\hline
\end{tabular}

The American College of Sports Medicine recently released a guide suggesting that physical activity should be maintained during the quarantine period as a result of COVID-19, emphasizing the importance for the health of every physically active minute. ${ }^{11}$

The study showed that approximately two thirds (62.2\%) of those evaluated live with at least two more people. Given that the advice during lockdown is to exercise at home, the social support of family members can be a motivating factor for physical activity engagement. Indeed, family support can increase adherence to a physical exercise program by $35 \% .{ }^{12}$ Interestingly younger adults had the greatest impact in reducing physical activities with social isolation reporting been sedentary 73.7\%, (Table 2) that might be related with a decrease in social interaction. Usually this age group is more likely to practice physical activity in groups or sports and some studies showed that social interactions and friendships significantly influence physical activity behaviors. ${ }^{13,14}$ 
Table 2. Relationship between sleep habits, food, physical activity, type of housing and sex by group at the first month of Pandemic.

\begin{tabular}{|c|c|c|c|c|}
\hline Age range & $\begin{array}{c}18-40 y \\
n(\%)\end{array}$ & $\begin{array}{l}41-60 y \\
n(\%)\end{array}$ & $\begin{array}{c}\text { Above 60y } \\
\text { n (\%) }\end{array}$ & $\mathbf{P}$ \\
\hline \multicolumn{5}{|c|}{ Type of housing } \\
\hline Apartment & $15(39.4)$ & $38(49.5)$ & $19(95)^{b, c}$ & \multirow{2}{*}{0.001} \\
\hline House & $23(60.6)$ & $39(50.5)$ & $1(5)^{b, c}$ & \\
\hline \multicolumn{5}{|c|}{ Sex } \\
\hline Female & $31(81.6)$ & $69(89.6)$ & $17(85)$ & \multirow{2}{*}{0.47} \\
\hline Male & $7(18.4)$ & $8(10.4)$ & $3(15)$ & \\
\hline \multicolumn{5}{|c|}{ Daily spend on activities } \\
\hline Sedentary (<1.5 Met) & $28(73.7)^{\mathrm{a}}$ & $34(44.2)$ & $13(65)$ & \multirow{2}{*}{0.007} \\
\hline Moderate-vigorous (> 3 Met) & $10(26.3)^{\mathrm{a}}$ & $43(55.8)$ & $7(35)$ & \\
\hline \multicolumn{5}{|c|}{ Number of meals do you eat a day } \\
\hline 1-3 meals a day & $23(60.5)$ & $51(66.2)$ & $16(80)$ & \multirow{2}{*}{0.32} \\
\hline Several meals & $15(39.5)$ & $26(33.8)$ & $4(20)$ & \\
\hline \multicolumn{5}{|c|}{ Meals quality } \\
\hline I choose healthy eating & $11(28.9)$ & $40(52)^{a}$ & $16(80)^{b, c}$ & \multirow{2}{*}{0.001} \\
\hline Sometimes & $27(71.1)$ & $37(48)^{\mathrm{a}}$ & $4(20)^{b, c}$ & \\
\hline \multicolumn{5}{|c|}{ As for weight } \\
\hline Maintained or lost weight & $17(44.7)$ & $43(55.8)$ & $10(50)$ & \multirow{2}{*}{0.52} \\
\hline Gained weight & $21(55.2)$ & $34(44.2)$ & $10(50)$ & \\
\hline \multicolumn{5}{|c|}{ Sleep time } \\
\hline Adequate hours & $30(79)$ & $50(65)$ & $11(55)$ & \multirow{2}{*}{0.14} \\
\hline Inadequate hours & $8(21)$ & $27(35)$ & $9(45)$ & \\
\hline \multicolumn{5}{|c|}{ Sleep quality } \\
\hline Peaceful sleep & $13(34.2)$ & $23(29.8)$ & $5(25)$ & \multirow{2}{*}{0.76} \\
\hline Irregular sleep & $25(65.8)$ & $54(70.2)$ & $15(75)$ & \\
\hline \multicolumn{5}{|c|}{ Physical Activity } \\
\hline Above $150 \mathrm{~min} /$ week & $25(65.8)^{\mathrm{a}}$ & $68(88.3)$ & $14(70)$ & \multirow{2}{*}{0.01} \\
\hline Doens't physical activity & $13(34.2)^{\mathrm{a}}$ & $9(11.7)$ & $6(30)$ & \\
\hline \multicolumn{5}{|c|}{ About physical activity } \\
\hline $\begin{array}{l}\text { Exercises I used to do } \\
\text { before the pandemic }\end{array}$ & $15(32)$ & $13(19.3)$ & $10(47.6)$ & \multirow{3}{*}{0.06} \\
\hline $\begin{array}{l}\text { I perform exercises that my } \\
\text { teacher plans for me }\end{array}$ & $27(57.5)$ & $40(59.7)$ & $10(47.6)$ & \\
\hline $\begin{array}{l}\text { I carry out researched } \\
\text { exercises on the internet } \\
\text { and social networks }\end{array}$ & $5(10.5)$ & $14(21)$ & $1(4.8)$ & \\
\hline
\end{tabular}

Font: The author (2020):* Chi-square test ; a- Young adults vs Middle-aged Adults ; b- Young adults vs Old cMiddle-aged Adults vs Old.

In the long run, this is a concern since sedentary behavior such as sitting, either watching television or using electronic devices, is associated with increased body weight in all age groups ${ }^{15-17}$ and increased risk of cardiovascular mortality. ${ }^{16}$ In our study, the 41-60 years-old group was the most active. Unlike the younger ones, middle-aged adults are considered the maturity group, in which the individual adjusts to civic and social responsibilities, establishing an economic standard that can maintain them as well as helping with family maintenance. Thus, they are more prone to choose and to develop leisure choices that lying on individual activities and not in groups. ${ }^{18}$

The present study showed a higher prevalence of physical activity among middle-aged adults compared to younger ones. This picture observed during isolation shows a behavior different from that observed in a period before the time of the pandemic, considering the VIGITEL study, which identified a higher prevalence of active individuals at leisure decreasing with age. ${ }^{19}$ Moderate-intensity physical exercises promote protection against infections caused by intracellular microorganisms. ${ }^{20}$ The practice of physical activity helps the immune system, physical exercises of moderate intensity are associated with a reduction in the incidence, duration and severity of respiratory tract infections. ${ }^{21}$

Prescription of exercise by a professional is considered important factor for the conduct of activities, outside the isolation period and also during the period of social isolation promoted by the Covid-19 pandemic. An interesting result of the present research showed that the majority of the participants were engaged in activities prescribed and planned by their teachers. From the point of view of health, this is of extreme importance, since, whenever possible, the prescription of physical activities should be performed by physical education professionals, as they have knowledge and can help practitioners guiding as to frequency, intensity, time, type of exercise, volume and progression. ${ }^{22,23}$

Social isolation associated with the decrease in habitual physical activity and changes in eating habits, which may lead to an increase in body weight and, consequently, contribute to overweight and obesity. ${ }^{23}$ In this sense, the results of the research show that the majority of participants opted for a healthier diet in this period, especially the middle age and elderly groups.

Although no significant difference in body weight gain was observed in the results in this period, a good immune response depends on a balanced diet and nutrition. Thus, more than ever, in this period of isolation of COVID-19, broader access to healthy foods should be prioritized and individuals must be aware of healthy eating habits to reduce the susceptibility to disease. ${ }^{24}$

As for the quality of sleep, there was no significant difference between the groups, however in the three groups around two thirds of the individuals reported irregular sleep. Knowing sleep habits is important because of its fundamental role in the immune system and in regulation emotionally, during periods of isolation there may be changes in sleep due to a break in routine and irregular sleeping and waking times. ${ }^{4,25}$

A limitation of this study is that it was carried out in a convenience sample, which limits the external generalization of the findings. In addition, self-reported questionnaires were used. Thus, in view of the exponential advance of this pandemic in Brazil, it is important to recommend health professionals so that the population has a physically active life.

\section{CONCLUSION}

It was concluded that social isolation promoted a greater negative impact on physical activity habits in the younger group (young adults), who used more time in sedentary activities. The elderly chooses better the food they eat and there were no differences between groups regarding sleep habits. The majority of the participants were engaged in activities prescribed and planned by their teachers. Apparently, the prescription of exercise by a professional is considered important factor for the conduct of activities during the period of social isolation promoted by the pandemic of Covid-19.

\section{ACKNOWLEDGEMENTS}

The second author (V.A.L) was supported by the Coordenação de Aperfeiçoamento de Pessoal de Nível Superior - Brasil (CAPES) and the last author (N.L.) was supported by the Conselho Nacional de Desenvolvimento Científico e Tecnológico (CNPq).

All authors declare no potential conflict of interest related to this article

AUTHORS' CONTRIBUTIONS: Each author made significant individual contributions to this manuscript: LMSB, conceived the study and participated in the statistical analysis, design and coordination, and writing of the article. JM and LPM critical analysis of the manuscript. VAL data collection and critical analysis of the manuscript. NL conceived the study and participated in its design and coordination, and critical analysis of the manuscript. 


\section{REFERENCES}

1. World Health Organization. Coronavirus Disease (COVID-2019) Situation Reports. Coronavirus Disease 2019 (COVID-19) Situation Report. 2019 [Accessed 20 april 2020]. Available in: https://www.who. int/emergencies/diseases/novel-coronavirus-2019/situation-reports.

2. Onder $M$, Rezza $G$, Brusaferro $S$. Case-fatality rate and characteristics of patients dying in relation to COVID-19 in Italy. JAMA. 2020;323(18):1775-6.

3. Guangdi L, DeClercq E. Therapeutic options for the 2019 novel coronavirus (2019-CoV). Nat Rev Drug Discov. 2020;19(3):149-50.

4. Brito LMS, Boguszewski MCS, Souza MTR, Martins F, Mota J, Leite N. Indoor physical activities, eating and sleeping habits among school adolescents during COVID-19 pandemic. Rev Bras Ati Fis Saúde. 2020;25:1-6.

5. Hallal PC, Andersen LB, Bull FC, Guthold R, Haskell W, Ekelund U. Global physical activity levels: surveillance progress, pitfalls, and prospects. Lancet. 2012;380(9838):247-57.

6. Wen-Bing H, Cheng-Ping L, Chun-Wen CT. Classification of Age Groups Based on Facial Features. Tamkang Journal of Science and Engineering. 2001;4(3):183-92

7. Rosmana T, Chasiotisa A, Kerwera M, Steinmetza H, Wedderhoffa O, Bosnjaka M. Will COVID-19-related economic worries superimpose the health worries, reducing acceptance of social distancing measures? Leibniz Institute for Psychology Information (ZPID). Psych Arch. 2020:1-6.

8. Sichieri, R, Coitinho, Denise C, Monteiro, JB, Coutinho, WF. Recomendações de alimentação e nutrição saudável para a população brasileira. Arq Bras de Endocrinol \& Metab. 2000;44(3):227-32.

9. Hirshkowitz M, Whiton K, Albert SM, Alessi C, Bruni O, DonCarlos L. National Sleep Foundation's sleep time duration recommendations: methodology and results summary. Sleep Health. 2015;1 (1):40-3.

10. Organização Mundial da Saúde (OMS). Inatividade física: um problema global de Saúde Pública. 2020 [Access in 12 jun. 2020]. Available in: https://www.who.int/dietphysicalactivity/factsheet_inactivity/en/.

11. American College of Sports (ACSM). Staying physically active during the coronavirus pandemic. 2020 [Access in 12 jun. 2020]. Available in: https://www.acsm.org/read-research/newsroom/news-releases/ news-detail/2020/03/16/staying-physically-active-during-covid-19-pandemic

12. Rhodes RE, Martin AD, Taunton JE. Temporal relationships of self-efficacy and social support as predictors of adherence in a 6-month strength-training program for older women. Percept Mot Skills. 2001;93(3):693-703.
13. Macdonald-Wallis K, Jago R, Sterne já. Social Network Analysis of Childhood and Youth Physical Activity. Am J Prev Med. 2012;43(6):636-42.

14. Montgomery SC, Donnelly M, Bhatnagar P, Carlin A, Kee F, Hunter RF. Peer social network processes and adolescent health behaviors: A systematic review. Prev Med. 2020;130:1059.

15. Tanaka C, Reilly JJ, Tanaka M, Tanaka S. Changes in weight, sedentary behaviour and physical activity during the school year and summer vacation. Int J Environ Res Public Health. 2018;5(4):915

16. Cureau FV, Sparrenberger K, Bloch KV, Ekelund U, Schaan BD. Associations of multiple unhealthy lifestyle behaviors with overweight/obesity and abdominal obesity among Brazilian adolescents: a country-wide survey. Nutr Metab Cardiovasc Dis. 2018;28(7):765-74.

17. Banks E, Jorm L, Rogers K, Clements M, Bauman A. Screen-time, obesity, ageing and disability: findings from 91266 participants in the 45 and up study. Public Health Nutr. 2011;14(1):34-43.

18. Rosa M. Psicologia Evolutiva. Petrópolis, RJ: Vozes; 1994.

19. Ministério da Saúde. Vigitel Brasil 2016: vigilância de fatores de risco e proteção para doenças crônicas por inquérito telefônico. 2017 [Access in 13 jun. 2016]. Available in: http://www.saude. gov.br/images/pdf/2017/junho/07/vigitel_2016_jun17.pdf

20. Terra R, da Silva SAG, Pinto VS, Dutra PML. Effect of exercise on immune system: response, adaptation and cell signaling. Rev Bras Med Esporte. 2012;18(3):208-14.

21. Nieman DC, Wentz LM. The compelling link between physical activity and the body's defense system. J Sport Health Sci. 2019;8(3):201-17.

22. Jiménez-Pavón D, Carbonell-Baeza A, Lavie C. Physical exercise as therapy to fight against the mental and physical consequences of COVID-19 quarantine: Special focus in older people. Prog Cardiovasc Dis. 2020;63(3):386-8.

23. American College of Sports Medicine, Riebe D, Ehrman JK, Liguori G, Magal M (Orgs). ACSM's guidelines for exercise testing and prescription. 10th Ed. Philadelphia: Wolters Kluwer; 2018.

24. Grande AJ, Keogh J, Silva V, Scott AM. Exercise versus no exercise for the occurrence, severity and duration of acute respiratory infections (Review). Cochrane Database Syst Rev. 2020;4(4):1-68.

25. Almondes KM. Manejo das alterações de sono no contexto de enfrentamento da COVID-19. Socie Bras de Psic. 2020;8:1-9. 